\title{
РЕГИОНАМ РАССКАЗАЛИ о создании интеллектуальных транспортных систем
}

\author{
О.Омелина, главный специалист \\ отдела пресс-службы ФАУ "РОСДОРНИИ"
}

DOI: $10.22184 / 2070-8963.2020 .90 .5 .30 .31$

ФАУ "Российский дорожный НИИ" регулярно проводит вебинары на актуальные темы в дорожной отрасли. На очередном онлайн-мероприятии речь шла об интеллектуальных транспортных системах (ИТС): как их спроектировать, чтобы в городе значительно уменьшились пробки, чтобы система сама в режиме онлайн перекрывала транспортные потоки или перераспределяла их. Также была поднята тема изменений в законодательстве Российской Федерации в части расширения практики применения контрактов жизненного цикла в дорожной отрасли.

Главное внимание на вебинаре было уделено теме интеллектуальных транспортных систем. Михаил Белов, заместитель начальника управления ИТС ФАУ "РОСДОРНИИ", рассказал о концепции создания ИТС субъекта Российской Федерации. Докладчик тут же обозначил ключевую проблему, с которой сталкиваются регионы. Ведь по результатам анализа экспертов РОСДОРНИИ в подавляющем большинстве регионов имеются элементы интеллектуальных транспортных систем, но их работа не налажена: "У всех есть и средства фотовидеофиксации, и весогабаритного контроля, во многих регионах есть платные парковки, адаптивное светофорное регулирование и многое другое. Но сейчас эти инструментальные подсистемы ИТС эксплуатируются совершенно разными организациями, решают в основном ведомственные задачи, связи между ними практически нет", - сформулировал проблему Михаил Белов.

Спикер особо подчеркнул необходимость взвешенного подхода к вопросу создания ИТС в регионе с учетом перспектив ее дальнейшего развития. Очень важно понимать, что внедрение таких систем, предусматривающих автоматизацию процессов управления дорожным движением в городских агломерациях, включающих города с населением свыше 300 тыс. человек, которое ведется в рамках реализации мероприятий национального проекта "Безопасные и качественные автомобильные дороги" (БКАД), - это первый шаг в создании ИТС субъекта РФ. И было бы правильно говорить о внедрении в городской агломерации элементов региональной ИТС.

М.Белов наглядно показал подходы к созданию ИТС субъекта Федерации, отметив, что создание полноценной ИТС - это сложный и небыстрый процесс. Однако, учитывая модульную архитектуру системы, первые положительные результаты от внедрения ее элементов можно получить очень быстро. Использование ИТС позволит иметь современную безопасную транспортную систему с единой платформой управления, которая сможет в режиме реального времени оценивать состояние транспортного потока, информировать граждан о ситуации на дороге. Организация комфортной сети пассажирских перевозок, умных остановок - еще одно преимущество проекта. Причем в перспективе все региональные ИТС будут связаны с федеральной системой и объединятся в единую национальную сеть.

Важно отметить, что ИТС - не обособленная структура. Она должна органично вписаться в проект "Цифровой регион".

Максим Порохов, заместитель начальника управления ИТС РОСДОРНИИ, подробно рассказал о процессе 
проектирования системы. Главный принцип создания ИТС - разработка всех сервисов транспортной сети с учетом требований конкретного региона. Это и создание схемы расположения видеокамер, и табло для отображения информации, и детекторов движения транспортных средств, и многое другое. Благодаря грамотному подходу к составлению проекта станут возможными обеспечение рационального распределения транспортного потока, снижение нагрузки на дороги, снижение количества пробок и ДТП.

"Мы должны объединить все существующие и необходимые подсистемы в регионе в единую систему и научить ее быть готовой к различным ситуациям на дороге с реагированием согласно разработанным сценариям. Все происходит в автоматическом и полуавтоматическом режимах. Приведу пример: происходит изменение температуры и влажности, что может привести к обледенению на дороге. Система сама информирует участников движения об опасности обледенения и на табло высвечивает рекомендацию снизить скорость. Процесс проектирования ИТС - это, по сути, увязывание в единую систему тех сервисов, которые необходимы для решения существующих проблем в "больных" точках региона", - объяснил М.Порохов.

Поэтому на первом этапе проектирования нужно провести исследование региона, его особенностей. Например, мест скопления транспорта, пробок, чтобы установить новую более современную светофорную группу. Кроме того, собирается информация о местах, где чаще всего происходят ДТП. Докладчик призвал представителей регионов уже сегодня начинать собирать и обрабатывать эти данные в своих субъектах.

ИТС неразрывно связана с транспортным планированием в регионе. Своими знаниями в этой области со слушателями поделился Иван Козельский, заместитель начальника отдела методического обеспечения транспортного планирования РОСдоРНИИ. Он начал с важности транспортного планирования. Оно позволяет управлять транспортным спросом так, чтобы избежать многочасовых пробок, пустых автобусов большой вместимости на одном направлении и забитых малой - на другом. Спикер наглядно показал, как любое воздействие на транспортную систему меняет картину движения, будь то запрет маневра на перекрестке, создание нового маршрута для перевозки пассажиров или строительство жилого комплекса. На этом примере особенно наглядно можно проследить преимущество не только транспортного планирования, но и его совокупности с ИТС.

"Представьте, что на пустыре планируется строительство ЖК с несколькими высотными зданиями.
Мы понимаем, что жители создадут большую нагрузку на транспортную сеть. При существующей организации дорожного движения 100\% автовладельцев будет выезжать на одну улицу, перегружая ее. При планировании организации дорожного движения мы ставим знак, разрешая ехать не только прямо, но и налево, что позволит перераспределить поток. Однако такая организация не способна оперативно реагировать на ситуацию. Третий вариант - ИТС. Мы ставим табло, которое благодаря системе, оценивающей, что происходит вокруг, воздействует на транспортный поток", - пояснил И.Козельский.

Этот пример показывает, что ИТС - мера совершенно иного уровня. Электронные табло также могут оповестить водителя об аварии впереди, о наличии ремонтных работ, что даст возможность построить альтернативный маршрут. Все это происходит за счет датчиков, которые способны оценить ситуацию на дороге, за доли секунды сформировать краткосрочный прогноз на ближайшие 5-10 мин и принять решение: например, перекрыть въезд в тоннель, если внутри случилось ДТП.

По вопросу обеспечения информационной безопасности при проектировании ИТС выступили Азрет Тебердиев, главный специалист отдела внедрения цифровых технологий обустройства автомобильных дорог РОСдОРНИи, и эксперт Александр Смирнов. Специалисты рассказали, какими документами следует руководствоваться при обеспечении безопасности объектов критической информационной инфраструктуры в составе ИТС. Речь, в частности, идет о приказах ФСТЭК России и ФСБ России. Был затронут вопрос - на что нужно обратить внимание при проектировании ИТС, чтобы не создать угрозы персональным данным.

Изменениям нормативно-правового регулирования относительно контрактов жизненного цикла (КЖЦ) был посвящен доклад Айгозель Байлиевой, начальника отдела разработки и внедрения системы КЖЦ в транспортной отрасли РОСДОРНИИ. Она сообщила, что с2019 года Министерство транспорта России совместно с Российским дорожным НИи работает над модернизацией законодательства в части расширения практики применения КЖЦв отрасли. Основные изменения, которые уже внесены в НПА, связаны с расширением перечня случаев заключения таких контрактов. Речь шла и о планируемых изменениях в законодательстве по данной тематике, внесении поправок в закон от 5 апреля 2013 года № 44-Ф3 ", где планируют закрепить понятие этапа контракта, обозначить поэтапное обеспечение КЖЦ и выносить на общественное обсуждение контракты стоимостью свыше 2 млрд руб. 